Final Draft submitted to:

\author{
Journal of Islamic Marketing, (20 I 3) Volume 4, Issue I \\ (Emerald Group Publishing Ltd)
}

\title{
Islamic Marketing - a challenger to the classical marketing canon?
}

\author{
Jonathan A.J. Wilson, University of Greenwich, London UK \\ John Grant, Author of "New Marketing Manifesto", and "Green Marketing Manifesto"
}

\section{Corresponding author}

Dr Jonathan A.J. Wilson

j.a.j.wilson@gre.ac.uk

Department of Marketing Events and Tourism, University of Greenwich, Old Royal Naval College, Park Row, London, SEI0 9LS, UK. 


\begin{abstract}
Purpose - To debate what (if anything) is Islamic marketing? And link developments in this field to the wider marketing paradigm.

Design/methodology/approach - A phenomenological antipositivist review of key case examples, drawing from 40 years of the author's collective professional experiences; and field notes investigating approximately I,000 brand marketing media reports, and 32 indepth interviews - as industry active academic practitioners. Supporting this, literature searches covered the fields of marketing, cultural studies, anthropology, contemporary religion, post-structuralism and natural philosophy.
\end{abstract}

Findings - Marketing is both a concept and lived experience, manifest in the competitive exchange of commoditised thoughts, feelings, actions and objects - between engaged individuals and collectives. For many reasons, Islamic and Brand agendas/imperatives have risen in the consciousness and practises of Muslims and non-Muslims globally, through social interactions. These have placed Islamic, Brand and Marketing practises in the spotlight, singularly and collectively. On the surface, many have considered whether Islamic marketing is a truism, a phenomenon, a noumenon, an ideology, or even a paradigm? We suggest that it represents a new focal phase 'torchbearer', as a conspicuous and necessary challenger strain towards convention, supporting fit for purpose marketing - just as 'Green' and 'Digital' marketing have previously, and continue to do so.

Research limitations/implications - This is a viewpoint piece, which whilst based upon the experiences of two authors, draws from their varied practitioner-engaged action research, as collaborators and participants. To this end they adopt a standpoint, which argues for marketing being an applied science, rejecting approaches that encourage academic/practitioner divides.

Practical implications - Scholars and practitioners should resist the temptation to study and practice the field with a silo mentality. Marketing is not monolithic, nor is Islamic marketing necessarily a new phenomenon, or discrete sub-set. Muslims have always engaged in marketing practices - offering symbolic and functional value globally.

Originality/value - We present the following key argument: that Islamic Marketing is (while connected to the Islamic faith, heritage and cultural milieu) most usefully described and analysed as a differentiated wave within marketing activities and consumption, spearheaded currently by Muslims and non-Muslims alike. And hence that it can be related to other developments in the marketing field, where marketing moves through evolutionary and revolutionary phases of meaning and practice, while grappling with new challenges and channels, in order to maintain its relevance and efficacy.

Keywords Islamic marketing, branding and advertising; Muslim consumer behaviour; Marketing phenomena; Marketing education; Marketing Theory and Practice; Culture; Consumption; Globalization.

Paper type Viewpoint. 


\section{What (if anything) is Islamic Marketing?}

If you accept the notion that marketing can be defined in a static, monolithic (business school textbook) way, as a finalized and authoritative MARKETING... then Islamic Marketing could likely only be thought of as a footnote, addendum, or subset.

Whereas, if you accept the idea of rapid fragmentation and innovation within a postmodern and globalising context for marketing, and that many successful new brands are associated with multiple emerging and competing 'other' strains of marketing; then it is easier to imagine Islamic Marketing becoming yet another such new strain - one that is not just different in content, or even in process; but based on different theoretical interpretations and subsequent practises too. So that core ideas like 'what is a brand?' and 'how do such brands relate to identity?' can change too.

The conventional MARKETING view would likely place Islamic Marketing under headings like:

- Niche marketing to ethnic minorities (using relevant media channels)

- Regional marketing with local relevance (using relevant cultural content)

- Political correctness (avoiding giving offence through cultural sensitivity).

"Yes but..." (The reader might protest), "Muslims account for $25 \%$ of people".

The scale of the audience, in itself, is not decisive. If the central assumptions and practices of MARKETING are not to be questioned, then it is only a matter of applying the same procedures (whether 4Ps, 7Ps or more) to a different audience.

This is an argument that has already been largely won in the case of Marketing to Women (' $50 \%$ of the population'), and the Over 50 s (' $40 \%$ of leisure spending'). Both of these have been trumpeted as new paradigms. But by failing to show a real difference in underlying marketing practice or theory, neither has found real differentiation.

If Islamic Marketing were such a subset, the history of these similar developments suggests that the answer to the question "What is Islamic Marketing?" would be that it is "the sales pitch of specialist communications and research agencies". We've seen such specialists emerge around specific audiences, like 'Generation Y'. And indeed there are Islamic Marketing agency units already; witness Ogilvy Noor. Not to suggest that their own vision of Islamic marketing is conventional; but merely to point out that specialisms within agency offerings do not necessarily entail marketing in that different a way - they may just be more clued up and relevant than their mainstream equivalents.

A more substantial subset (but still within the MARKETING hegemony), can be established by industry verticals and value chain intermediaries. Financial Services, Tourism, Organic Food, and Country Branding are just some examples of domains which deem themselves different enough to require specialists. Similarly specialisations exist within the marketing mix, like Direct Marketing. Such domains have made good topics for books, events, journals, shared publicity campaigns and even shared brands (as in Anchor butter). But they have not entirely challenged the status quo. Rather, they have sought to elaborate niche applications of general theory. It could perhaps be argued that both Halal and Shariah Finance fit this mould? Both of these - like Financial Services, Pharma and others - are partly different, because of the need of practitioners to understand 'regulatory issues' and compliance. 


\section{Searching for antonyms to the canon of Monolithic marketing?}

All of the points raised assume one fixed, established, authoritative MARKETING. But what if this monolithic (one theory and practice suits all) paradigm were destabilised?

This dominant theory of MARKETING reached its height in the 1980s when new brands (Nike, Apple) joined the established brands (Coca-Cola, McDonalds) in appearing to confirm that we had reached an "End of History" in liberal consumer capitalism of the American variety. With foreign exceptions (Sony, Chanel) only seeming to be proof of the universality of this 'American Dream' individual-lifestyle-identity-aspiration marketing rulebook. The launch and subsequent global spread of MTV, along with global crazes like The Walkman, also seemed to suggest 'a global teenager' presaging a unified consumer market too.

However, like many social developments, the moment of its apparent triumph was when the old MARKETING paradigm started to crumble. Since the 1990s a number of challenger strains of marketing have emerged. These started as lone exceptions, but quickly came to represent radically 'other' ways of doing marketing and thinking about how it works. Some challengers eschewed the typical above the line media (for instance Virgin relied largely on PR). Others used it, but in very new ways (for instance Benetton, whose marketing communications were political statements with no obvious connection to the brand, other than it being a rather 'Italian' approach?) Some grew quickly on the alternative approaches offered by new marketing channels and new ways of relating to customers.

This is a trend that we have been tracking, commenting on and participating in as practitioners. Our respective books and publications have charted a number of these challenges as phenomena, as they emerged. Our case studies have often been from different markets (media, services, retail, technology, sports, music) than the fast moving consumer goods (FMCG) on which a lot of 1960s marketing theory was built. But it was not only the 'who?' which challenged the MARKETING canon, but the 'how?'

A prime example is New Media - Internet, experiential, community, interactive - which has led to a 'New Marketing' (Grant, 2000) that is more participative, negotiated, interactive, vision and cause related, and less objectified. Not all brands have adopted this approach, but it has proved a particular boon to those like retailers, mobile operators and banks, for whom customer loyalty and relationship are the key drivers of brand value and profit.

The latest developments in this trend involve located, real-time, touch (or Near Field Communication) interactive, application-based smart mobile media. New theories abound. For instance the 'Omnichannel' theory of retailing (Rigby, 20II), which sees offline and online services not only converging, but recombining in creative and disruptive new hybrid platforms - such as visiting a physical store, but interacting largely digitally (as with Apple self checkout); or reviewing purchases (and alternatives) online as you buy; all made possible by the growth of smart phones. This has opened the possibilities of real-time, located marketing both by retailers (e.g. Burberry) and also authoritative intermediaries (e.g. GoodGuide)

As we discussed in The New Marketing Manifesto, (Grant, 2000); and 'Cultural Stakeholderbased Brand Management Phenomenon' Wilson (20I2a), it became painfully apparent quite early in the new media era that many of the supposedly permanent tenets of MARKETING were generalisations of a temporal, contingent set of tools. The marketer is also a consumer, and the consumer is also a marketer - power is subject to dynamic space and context, self-defined legitimacy, and real-time. 


\section{Humanising Brands}

The edifice of Brand Personality is one of the central tenets of old MARKETING. Its idea being that people make decisions not on functional and financial criteria alone, but because of a felt 'fit' between the brand personality and their own lifestyle, demographic and identity. This notion was introduced in the writings of 1960s 'Madmen era' marketing gurus such as David Ogilvy, Pierre Martineau and Ernest Dichter - and grew out of the then novel practice of using personalities in adverts (like the Marlboro Cowboy) especially in the new personality led media of television (like the Jolly Green Giant). From this, brands became progressively viewed according to schools of thought, which judged them less about hard economics and more according to identities, personalities, relationships, communities, and most recently cultures. Over time, this evolution became enshrined as a universal theory of brands - with the messianic idea that brands (as modern deities) and their personalities are our friends, say something about us, and shape who we are. But what is the 'personality' of eBay? (Grant, 2002). In tandem, Aaker (1999) has suggested that consumer experimental psychology research has examined the self-expressive role of brands, but has found little support for the premise that the interaction of the personality traits associated with a brand and those associated with an individual's self-concept influence attitudes. Rather the role of the 'malleable self congruity' in connection with situational cues and possessions play a more significant role (Belk, 1975; 1988). If brands are our friends, then invite Facebook for dinner! Furthermore, how do you judge your Facebook and Linkedln friends, largely represented by an avatar, eye-catching strapline and an automated reminder. Are they more brands than they are friends?

Similarly, the idea of Positioning (targeted offerings to distinct audience segments) became problematized - both by postmodern doubt and by digital possibilities. As Nicholas Negroponte announced in Being Digital (1996), "In the digital universe I am not a statistical subset, I am Me.". And he was proved right. Banks formerly used to target a range of customer segments that were 'pen portrait' stereotypes; but increasingly now they treat customers to individual targeting, based upon their unique fingerprint of historical data interactions (in much the same way as Amazon recommends to its customers).

This means that we have seen the decline of advertising, engineered mainstream media, and ethnic channels, as we know them now. Instead, 'raw' cultural and authentic media content, linked to embedded interactive situation-based advertising-esque roll-over messages will be selected, downloaded and assembled according to the diet and tastes of the individual, and consumed on dual screens... the same platforms, as empty vessels waiting to be filled and viewed by different collective individuals and their own lenses.

And on a practitioner level, the elements and concepts of strategic briefing for communications have changed; indicating a basic shift in what marketers agree that they are doing (their 'theory in use'). When faced with writing a brief for commissioning a documentary, creating an experience or event, commissioning branded content and so on... the old categories in the paid for advertising briefing forms like "what is the single minded proposition?" no longer seemed to apply as well. The focus shifted to exploring how the new media platforms would achieve objectives for the brand, not what they would say. 


\section{The muscular marketing scrum}

Other challenges to monolithic MARKETING we have been tracking include:

Innovation: brands like Twitter, Instagram and Apple become the (fragile) holders of the 'Golden Bough' of being simply the new new thing, appealing to what Anthony Giddens (199I) described in Modernity and Self Identity, as a new universal imperative to "keep up with the times". Now is the age which heralds the marketing of such brands being about interpersonal visibility and imitation - like the use of white headphones, AIDS ribbons, Beats by Dre headphones (especially the over-sized cans in public), 'Movember' handlebar moustaches, and ' $\mathrm{V}$ for Vendetta' masks as 'badges' of currency. A darker side of these trends has also seen flash-mob mobilized, white mask wearing German neo-Nazi youth, calling themselves 'Die Unsterblichen' (The Immortals), speaking out against Turkish immigrants.

Sustainability: this is problematizing many conventional tools of marketing, because they lead you to hype selectively; also known as 'Greenwash' - as amply demonstrated by BP's "Beyond Petroleum" fiasco. Instead, sustainable marketing activities involve approaches like dynamic multi-stakeholder collaborations and co-operation that are magnetized by a shared cause (Grant, 2010; Wilson, 2012a) - like Levi's adoption and appeals on behalf of the economically depressed US blue-collar town of Braddock. There is increasing recognition that sustainability is not a department, but is about everything you do, and programmes have been used to align sustainability with both corporate strategic objectives and marketing practice at leading companies such as Unilever and Coca-Cola.

Entrepreneurship: where the story of the company, its exploits and successes become the heart of the brand - a 'reality TV' style bandwagon strategy that worked not only for literal entrepreneurs like Branson, but also for Obama08. What this challenges is the whole notion of brand as (product or corporate) façade - presented to an external audience as opposed to cultivating insiders.

Lifelong Learning: Brands grew up as a convenient way to make fast decisions between similar products (so that it hardly mattered anyway), or top of the mind awareness, without much thought. This construct is vulnerable to growing consumer expertise and agency. For example, a revolution took place in food and drink, where conventional brand MARKETING came to signify low value (fast food, or processed). Now hail the prominence of the ingredient brand (Halal, Kosher, Fair Trade, 5 A Day, Soil Association etc.).

'Teaching' marketing before practise: how marketing theory and practice are taught in universities and workshops internationally. "When in Britain, do as the British do - if anyone knows that that means. Multiculturalism in a 'British' university business school" focused on this trend (Wilson, 2010). The inference being that little is done to cater for the cultural needs of international students and delegates linked to the subject; and this leads to firstly, a sporadic transmission of vital tacit information; and secondly, an assumption that poor performance on assessments indicates a lack of marketing know-how. This is also based upon the assumption (by institutions and applicants) that if students have English language proficiency, have the paper entry requirements, and the campus is international student 
'friendly', then marketing proficiency and aptitude can be transmitted and assessed along universal scales.

Within this paradigm the bar is raised high for students, textbook authors and especially tutors. Marketing multiculturalism is assumed through diverse cohort demographics and multicultural class interactions. Wilson (2010) cites tutoring close to 100 nationalities in any year in London; with London hailed continually as celebrating its multicultural and pluralist campuses - more so than elsewhere. When writing this, we reflected upon the headscarves, full face veils, turbans, skull caps, mohawks, dreadlocks, tattoos and body piercings, which punctuate the aristocratic, World Heritage 'Old Royal Naval College' site and campus to the University of Greenwich, London - as a case in practice. However do such conflations ratify proclaimed monikers of truly 'global marketing' courses, scholars and practitioners; and is there further interrogation of the 'emptiness' of racial and colonial signifiers, as reported by Gilroy $(2002,2004)$ ? Furthermore, Liu and Wilson (20I I) find that whilst there is evidence to suggest that training needs in leadership and management programmes across continents are generally met, this is only in the short term and long-term needs are yet to be addressed. Also, in support of long-term objectives, the ability to recognise and accommodate religion and culture remain areas necessitating further understanding.

Case examples and materials may have become more international, but the method of transmission and environment in which participants share their views still favours some cultures over others. And, when reviewing marketing curricula, how much time is actually spent studying culture and religion - when outside of sterile and apolitical classroom laboratories, they appear to occupy a much greater slice of life?

Osmotic culture and 'class': Cultural branded phenomena like sport, music and fashion are transnational, viral, and born global, through social media and the Internet. Also, they are crossing and joining classes, cultures and ethnic groups. In doing so, such traditional notions of 'high or upper class' and luxury, interrogated by post-structuralist schools, are being redefined and challenged. This is beyond the assumptions of Saussure (1974), LéviStrauss (1968), and Wright (1975) of an underlying structure along axes of binary opposition (Storey, 2009). Derrida's (1973) différance, of both the structural and temporal relations before and after; Barthes's (1973) mythologies of Primary signification, Denotation, Secondary signification, and Connotation; and Foucault's (1989) Power, which produces domains of objects and rituals of truth in positive terms; each highlight cultural complexities and reciprocity. Storey (2009) identifies that,

"perhaps the most important consequence of the new sensibility, with its abandonment of the 'Matthew Arnold notion of culture, finding it historically and humanly obsolescent' (Sontag, 1966 p.299), is its claim that the distinction between "high" and "low" culture seems less and less meaningful' (Sontag, 1966 p.302); (p. I83).

Cricket, white collar boxing, hip hop, jeans, retro, 'street', 'urban military chic', 'bling', 'cool', 'geek' and 'nerd' are just some of the examples of how objects and lifestyle choices are being used to communicate celebrated complicated projected opposites, designed to convey authenticity - through subtle paradox. Dynamic and situation specific Class and Classiness. Even in the field of politics, when to go 'no tie', rolling up shirt sleeves, and inviting Jay-Z to battle your ' 99 problems' are indicators of how meaning is framed by storytelling linked to objects, cues, triggers and props - in an increasing Gestalt, fuelled by the Diderot effect (Wilson, 2012a; Baudrillard, 2005; Derrida, 2005).

Now in echoing the concerns of Said $(1985,1993)$, the subtle, persistent, romanticised and 
Eurocentric interpretations of Muslims and culture appear to prevail. Furthermore, with much analysis hailing from Western, English language publications, even when the 'other' is examined by those 'others' themselves, there still remains a danger that the same negative myths are now being propagated by 'natives'. We feel that a recent case in practice is the paper by Izberg-Bilgin (forthcoming), which concludes in Turkey that through a "consumer jihad [against global brands], informants accommodate and protest the social crises posed by modernity and globalization".

If this is a jihad (Arabic for struggle), we wonder how such positions would reconcile the consumption of smartphones, customized with religious apps.; bright colourful designer label headscarves; halal McDonalds and KFC chicken; Swiss watches; and Puma, Adidas, and Nike trainers? Anecdotally, we also remember seeing some Muslims in the Gulf leaving the baking sun of Friday prayer, leather clad with personalized biker gang logos, on Harley Davidsons. Surely fears of social crises drag the debate of Muslims in society back to structuralist and Orientalist debates? Because they would argue that such consumption is accepted as a necessary evil, but detested; Westernized folly; schizophrenic; or even hypocritical positions that we would reject (even if proclaimed by 'the native'). One reason being that terms such as Islamism and modernity mean little to Muslims, and they have been thrust upon them. And so as Lyotard (1984) has articulated through postmodernism, as a condition marked by a crisis in the status of knowledge in Western societies, it is however in a nascent and constant state of metanarratives. Also is the same framing applied to nonMuslims who eat halal; Westerners who use chopsticks, or adopt Asian dress codes on home soil, and holiday across the Muslim world; but exhibit traits of xenophobia? Or are such Westerners framed as trusted and open-minded civilized actors, reconciling legitimate concerns - through free speech and free omnivorous consumption?

For us, it is a further signal that class and even classiness need further emic and etic investigation - especially according to concentric levels of culture in Muslim majority/minority, Asian, African, Middle Eastern and even European/North American settings. This is not to say that we reject the study of Global (largely US and European) brands, but we should accept that they have been successful in learning and localizing their activities; and we should continue to search for further case examples from outside the well-trodden pages of marketing text books. Also, this pursuit is not to affirm self-fulfilling prophecies or pinpoint contradictions; rather in fact the presentation of case evidence necessitating deeper erudition. Therefore, culture is less about a 'clash' and more about a process of cultural osmosis.

Commoditized cool: Belk, Tian and Paavola (2010), chart how 'cool' has migrated from its roots in being "grace under pressure" (Thompson, 1983, p.16, cited in Belk, Tian and Paavola, 2010) into becoming "a low profile means of survival and later a youthful rebellious alternative to class-based status systems..." to finally being "commoditized" - following the style most strongly articulated by African American males (pp.183, 187). Comparable to the identified Muslim phenomenon, interest and developments in China's youth population of 500 million under the age of 30 have been studied by Bergstrom (2012). When presenting her arguments, Bergstrom uses emotive and poetic headings to group her findings, some of which are:

- Reclaiming style

- Untraditional faces

- Justice starts online

- A critical eye on brands 
- Political purchasing

- Testing boundaries through blogging

- The confidence of luxury

- Curating new symbols

- Graduating symbols

- Fashionably correct

- Going native

- Localizing without losing out

- Leveraging "see and be seen"

- Reversing currents

A recent article in creative industry magazine Fashion Collective by Deutsch (20I I), suggests that even for elite Luxury brands, "The present context of the world is conducive to the longing for tribal connections that engage people with 'Passion and Purpose'. The world is "between mythologies" - it is not what it once was and it does not yet know what it will become". While a report from the Boston Consulting group (20I2), suggests that Luxury markets are transitioning from artefacts to experiences.

All for one and one for all: From these cited examples, it appears that findings can be applied and generalized to Muslim geographies and the wider global community. It is less about the Chinese, Muslims, African Americans, or fashionistas, and more about unveiling and understanding humans behind their masks of 'commoditized cool'. If this position is held, then again it points towards consumers and marketing entering spaces and exchanges within common lived experiences - and creating a new sub-set of marketing terms alone, such as Islamic marketing, will do little to change marketing practices meaningfully.

Authenticity: Running through all of these is a quest for real-time authenticity, linked to appropriated heritage and pedigree. People still want to buy 'The Real Thing'. They may have lost faith in brands like Coca Cola that claim in classical MARKETING terms to provide this. Instead authenticity is to be found in new marketing formats. Similar products can still thrive (like Red Bull), but the means and terms of engagement are all new. Red Bull established itself as authentic through event marketing and canny distribution placement, rather than above the line advertising which they only used late in their history and still in a secondary role. They recently took marketing to new heights (literally) when they sponsored a sky dive from outside the earth's atmosphere broadcast it live on the web (SPACE.com, 20I2). 


\section{Civilised sedentary Muslim life - commoditized sacred, profane, and mundane}

Islamic culture certainly seems capable of problematizing many assumptions and practices of Western marketing. Contrary values central to Islamic culture - like modesty, nobility, sacrifice, struggle; in turn eschewing the 'icon worship' identification (so prevalent in Western advertising) could enrich storytelling. Instead, storytelling with a commitment to artistic design, craft and beauty; a sacred feeling of reverence, for beauty and craft; and a commitment to Unity appear to follow more Eastern mythological values. Even when the same brands are being bought in different cultures, do they still mean the same thing? Are luxury goods, evidently popular in Muslim markets, still grounded in competitive envy (Berger, 1972) or lack of aristocratic grace (Baudrillard, 2004)? Or are they rather about being the same as others around you regardless of race and class - identity grounded in conspicuous or inconspicuous collectivism, rather than individualism? Reference groups now more than ever appear to be transnational nomadic tribes (Cayla and Eckhardt, 2008; Bardhi, Eckhardt and Arnould, 20I2). Furthermore, it would be a mistake to assume that this is just the domain of the East, or Muslims.

These seem more fundamental differences than simply 'French' vs. 'American' - and more akin to the differences between 'Japanese' and 'American'. And indeed some very distinctive brands have also emerged from Japanese cultural sensibilities - another prime example of new strains within the marketing canon. For example, Muji, whose name means 'no logo', whose ethos is eco and ultra low cost, and whose design philosophy derives from sources like Wabi Sabi (the idea expressed in traditional Japanese arts and rituals that beauty is to be found in naturalness; the impermanent, the flowing, the imperfect, the unfinished or incomplete). However, such comparative national/ethnic/cultural scales only tell part of the story. They might be models and exemplars, but they are didactic constructs, which run the risk of creating over-simplified mannequins that sleepwalk and compartmentalize evaluations into categories according to 'good' and 'bad', and the 'other' - rather than 'just is'.

Add to this the widespread view that we face even more change over coming decades, rather than less. For instance in Globality, Sirkin, Hemerling and Bhattacharya (2008), argue that we now face companies competing for everything (resources, markets, capital, IP, talent...) against every other company, everywhere... resulting in an inevitable shift in power away from the US, Europe and Japan. In this view, tomorrow's leading companies and brands will hail from not just form the USA and Europe, nor even just from the BRIC countries (Brazil, Russia, India, China), but also increasingly from what Goldman Sachs called the Next II - six of which happen to be Muslim majority countries. Rapidly developing economies like Turkey (benefitting from cheap credit) could also be placed alongside the rapidly transitioning economies; transitioning to democracy, from dependence on oil to diversification - many of whom have ample means to create their own new cultural brands to cement these new realities.

Some might argue that Western hedonism, as expressed in conspicuous consumer branded consumption is simply opposed to Islam. This plays into the hands of Samuel Huntington's "Clash of Civilizations". He was right to identify the fact that many cultures are based on religion; but his thesis that Islam "and its bloody borders" clash with most other civilizations and this is the "real [Global] problem", is something to be contested (Roskin and Coyle, 2008 Pp.280-28I). Furthermore, this belies the thousand years during which gorgeous fabrics, crafts and designs were traded across the Dar-al-Islam, across Africa, Arabia, Balkans, China, Hungary, India, and Spain amongst other territories. Evidently worldly goods... Evidently with symbolic as well as functional value... Evidently contributing to an ambience of Islamic 
beauty, craft and culture. Why, in a revitalizing Muslim world, might new artefacts not take this role? Along this line, we argue for further investigation into culture and consumption as an extension of the work by Belk (1988), McCracken (1990a, 1990b, 2008), Baudrillard (2005); Derrida (2005); and Gilmore and Pine II (2009) - but applied to more Muslim cultures and geographies.

\section{The Samurai, the farmer, the artisan, or the feminine Good Samaritan?}

As an allegory to religious practices, the martial arts have experienced similar phases of progression. Martial arts, like Islam and its different schools of thought, in essence are designed to serve different people, according to differing types, cultures and tastes. They are based upon the preservation of culture heritage and tradition - fused with evolutionary innovation addressing the here and now. When looking at martial arts key questions were asked within the past century. Should secrets be shared with foreigners, or 'others', and does this weaken the arts and national identity? Particularly in Japan, with an imposed pacifist constitution and martial warfare ban by the US upon occupation in 1945, the Japanese had to consider how martial activities could be reinstated and reframed as martial arts, or 'sport'?

More recently, within business and management institutions such as the Harvard Business School, amongst others, have conceptually and laterally interpreted then applied many martial arts constructs in the business world. Notably, the circa 2,000 year old Chinese text, Sun Tzu's The Art of War (which is also held in high esteem in Japan), can be found widely with duplicate copies in the business, philosophy and martial arts sections of Western book stores - with some versions carrying supporting commentaries and applications, specific to business. This is very much a classical standpoint: providing bedrock concepts to many executive training and MBA programmes - with the aim of galvanising 'the troops' on the modern day corporate battlefield.

Furthermore, with a wider movement towards civilized urbanism, social mass consumption and commodification, what is the impact of introducing an ethical position, which allows for charging money to train, for profit? (in the martial arts, worship, and education alike). Similar debates were had concerning selling copies of the Qur'an - a practice previously frowned upon, as it is the divine word of God. The martial arts and religion in the face of urbanization and civilization have seen them satisfy more than basic physiological, spiritual and safety needs, and more about aspiration civilization and sedentary life - points which have been considered by the classical scholar ibn Khaldun in I 377 (Wilson, 2012a,b).

Looking more recently at the Halal (permissible): objects, commodities, artefacts and activities - ranging from the sacred, the profane, to the mundane are being branded and labelled in the modern world. Whilst halal may apply to all of the items for which it is used to label, we wonder whether 'brand halal' and such branding approaches are fit for all of them? Wilson and Liu (20II) have observed how whilst halal labelling has offered reassurance, it has also encourage greater fear, suspicion, and reduced risk taking - all of which it is argued have reversed the spirit of what halal means and offers. Therefore, we raise the question that considers, what impact will this have on consumption and perceptions of what it means to be a Muslim? Will it lead to Muslim commercial strength and pride, at the expense of the more inner spiritual dimensions? Never more than now have meat producers have to deliver so many halal carcasses - anywhere up to 1,000 chickens in one day, in one abattoir. The spiritual link with nature and reverence for creation requires further meditation. Many Muslims celebrate Eid by paying for an online sacrifice of a lamb that they never see, given to recipients whom they never meet. This 
sanitized interpretation, albeit pragmatic solution, sacrifices the physical human bonds of kinship, and compassionate interaction with nature and animals, in order to fulfil functional religious compliance. With these in mind 'Halal' mass consumption and even mass communication are reaching a crossroads. From a spiritual standpoint, can quality, quantity, and economies of scales ever be reconciled truly with spiritual due diligence - or is this ideal of spiritual purity linked to restricted volumes a luxury, consumption and communication of the sage and his tribe of followers up in the mountains? Is there a risk that brand strength and equity will be used to raise revenues and commoditize in response to these challenges, which will muddy the essence of Halal consumption exchanges? We are now bigger tribes, spread across larger territories and these questions have become more critical than ever.

Also, following $9 / 1 \mathrm{I}$ we suggest that the significance of this event has forced Muslims to respond in a similar way to the Japanese. Through championing ambassadorial openness, culture, tourism, and education, Muslims as individuals and collectives are trying to steer a new path, attempting to reach out and readdress imbalances - both within and outside of their community. In addition, this appears to have encouraged a softer, more feminine strain of Muslim marketing, embracing reciprocity and exemplifying the story of the Good Samaritan.

Just as historically, Sufism came to champion the inner dimensions of worship in the warrior Caucasus of Central Asia; Hindu shadow puppets were used to explain Islam in Indonesia; and Qawwali music celebrated the glory of God in India; today Muslims seek to extend their 'labelled Islamic' hospitality and commodities across the globe; and to share their intimate feelings on social media platforms and user generated content sites. Many of our case studies find that regardless of religious observation, the phenomenon is wider than faith and is being championed by both practising and cultural or secular Muslims, with the same passion. And, that Islamic marketing appears to be the label by which people are now beginning to recognise and understand these aspirations.

The interesting polemic is that behind the backdrop of $9 / 1 \mathrm{I}$ and other media expressing negative views towards Islam, a significant number of nominally cultural or secular Muslims have still rallied closer under the flag Islam, when they could have chosen to step back. Therefore, we suggest that within the social sciences, conventional approaches towards defining and interpreting what a Muslim or religiosity is and mean need further investigation.

This is not to say that we are arguing for a better understanding of marketing universals, or universal differences - instead that principles should be revisited and re-evaluated, rather than extended along the idea of one common premise. Anatomically, physiologically, emotionally and intellectually, we (and marketing) all may share the same roots - but the focal lens with which reality is viewed is, can and will change. Islam states clearly that there will always be the seen and unseen beyond human comprehension. Plato talks of the transient and transcendent; and Imam Ghazali comments on the 'incoherence of philosophers'. Therefore, there is no reason why we all have to adopt the same lens; that one 'ossified' lens is better than the other; or we will all see the same thing. This by extension also applies to 'our view' of Islam and Islamic marketing - for Marketing and Muslims need to be understood through their cultures, exchanges and lenses.

\section{Marketing literature fit for practise?}

Finally, another area of concern lies in the fact that business and management literature frequently treats marketing as blanket term covering 'everything'. In practice 'Sales and Marketing', then 'Branding-Advertising-Public Relations' practitioners are very different 
beasts: fulfilling, existing and practising very different functions - with practitioners hailing from distinct and different backgrounds. When viewing things in this way, what does Islamic marketing even mean?

- Would a product be sold or created in a different way according to Islam, perhaps because the organization behind it espoused different values?

- $\mathrm{Or}$ is it more a matter of the expression of brands in ways relevant to this distinct culture, ethos and religion-derived worldview?

- Is Islamic marketing 'just' a matter of Islamic advertising, branding and PR as practised by these professionals?

- So is it really more about refining and redefining a universal code of ethics - and recognising that Islam and Muslims have offered inspiration and source material, as they have for centuries?

As cases in practice in the UK: those who study law at University have to study Islamic law and philosophy (along with Judaic and Hindu laws) as part of their studies - but they are still working towards a qualification in UK law. What is acknowledged are the foundations, links, commonalities and legacies of these other legal systems upon which UK law has been built. Comparably, for those that study science, they will study the scholarship, achievements and findings of scientists, some of whom happened to be Muslim and interpreted their findings according to knowledge and information contained within Islam - but this is still viewed as 'just' science.

\section{Conclusions}

In conclusion: what is Islamic Marketing? To date it has been treated as a specialism (at most) within an established, monolithic MARKETING. Rather, we hold Marketing as both a concept and lived experience, manifest in the competitive exchange of commoditised thoughts, feelings, actions and objects between engaged individuals and collectives. For many reasons, Islamic and Brand agendas and imperatives have risen in the consciousness and practises of Muslims and non-Muslims globally, through social interactions. These have placed Islamic, brand and marketing practises in the spotlight, singularly and collectively. On the surface, many have considered whether Islamic marketing is a truism, a phenomenon, a noumenon, an ideology, or even a paradigm? We suggest that it represents a new focal phase torchbearer, as a conspicuous and necessary challenger strain resistant to convention, ensuring fit for purpose marketing - just as 'Green' and 'Digital' marketing have previously and continue to do so. And so in principle, we are arguing that it could become another new strain of marketing.

Our key argument asserts that Islamic marketing need not be thought to be derived directly from Islamic faith, but rather filtered through more worldly actors and activities by Muslims and non-Muslims alike; as part of a natural phenomenon, where marketing moves through evolutionary and revolutionary phases of meaning and practice - in order to maintain its relevance and efficacy within new environments.

We have found in recent research for our new publications (in preparation) that there do seem to be encouraging, inspiring signs of brands, art and culture, and those of an authentic, confident new Islamic voice emerging. However many of the examples we would point to are formed in interaction with other cultures; and this suggests that scholars and practitioners should resist the temptation to study and practice the field with a silo mentality. Marketing is not monolithic, nor is Islamic marketing a new phenomenon, or necessarily a disconnected field. Muslims have always engaged in marketing practices offering 
symbolic and functional value globally. And for over a thousand years they have been masterful in absorbing ideas, sciences, aesthetics and adapting them to fit the Islamic ideal of Ihsan, or the inner Islam.

Promising though recent developments may be, such futures are never decided by conjecture alone, they are futures that can only be built through struggle. We will have to see if 'Muslim' marketers have the courage to match their convictions.

\section{Biographies}

John Grant John Grant is the author of Co-opportunity (2010), the award winning Green Marketing Manifesto (2007) and three other books. His first book, The New Marketing Manifesto (1999) was named one of the 10 Best Business Books of 1999 by Amazon.com. John was co-founder and head of strategy at creative agency St Luke's (as featured in the Harvard Business Review, Fast Company Magazine) in the mid 1990s. Since then, John has advised clients on brands, marketing, behaviour change, strategy, sustainability and innovation - with a particular focus on the three main global trends of sustainability, digital media and multiculture (convergence, fusion and creative diversity). John's clients have included the BBC, Cafe Direct, Capco, Cisco, the Co-operative Bank, Daylesford, Ecotricity, The Guardian, HSBC, IBM, IKEA, ING, innocent, LEGO, Microsoft, Nandos, Natura, Nokia, O2, Pictet, Philips, Shell, Sony Mobile, Unilever, the Royal Mail and various departments of the UK and Swedish governments. John has extensive international experience working with brands across Europe, North and South America and Asia.

Jonathan Wilson is Editor of the Journal of Islamic Marketing. He has over 15 years of collective academic and practitioner experience in the public and private sector specialising in marketing communications management, print and online media (advertising, sponsorship, sales, branding, public relations and events). As a practitioner, his work has been in the Internet, technology, video games, engineering, sports and music sectors. Jon's research looks at Brands, Halal, Sport, Culture, and Leadership. 


\section{References}

Aaker, J.L. (1999), “The Malleable Self: The Role of Self-Expression in Persuasion”, Journal of Marketing Research, Vol.XXXVI, February, pp.45-57.

Barthes, R. (1973), Mythologies, London: Paladin.

Bardhi, F., Eckhardt, G.M. and Arnould, E.J. (2012), "Liquid Relationship to Possessions", Journal of Consumer Research, Vol.39 (3), October pp.5 I0-529.

Baudrillard, J. (2004), The Consumer Society - Myths \& Structures, Translated by Chris Turner, London: SAGE.

Baudrillard, J. (2005), The System of Objects, London: Verso, New Left Books.

Belk, Russell W (1975), "An Exploratory Assessment of Situational Effects in Buyer Behavior," Journal of Marketing Research, II (May), pp. I 56-63.

Belk, R.W. (1988), "Possessions and the Extended Self', Journal of Consumer Research, Vol. I5, September, Pp. I39-168.

Belk, R.W., Tian, K. and Paavola, H. (2010), "Consuming Cool: Behind the Unemotional Mask”, Research in Consumer Behavior, Vol.I2, Pp. I83-208.

Berger, J. (1972) Ways of Seeing, London: Penguin Classics.

Bergstrom, M. (20I2), All Eyes East - Lessons from the Front Lines of Marketing to China's Youth, New York: Palgrave MacMillan.

Boston Consulting Group (20I2), "Well-Heeled Shoppers Speeding Up Shift from Products to Experiences in the Global Luxury Market", Press Release (Online), June $5^{\text {th }}$, http://www.bcg.com/media/pressreleasedetails.aspx?id=tcm:I2-10720I [Accessed: $2^{\text {nd }}$ Dec. 2012].

Cayla, J. and Eckhardt, G.M. (2008), "Asian Brands and the Shaping of a Transnational Imagined Community”, Journal of Consumer Research, Vol.35, August, Pp.216-230.

Derrida, J. (1973), Speech and Phenomena, Evanston: North Western University Press.

Derrida, J. (2005), The Politics of Friendship, London: Verso, New Left Books.

Diderot, D. (1964), “Regrets on Parting with my old dressing gown”, in Rameau's Nephew and Other Works by Denis Diderot, [trans.] Jaques Barzun and Ralph H. Bowen, New York: Bobbs-Merrill, pp.309-3I7.

Deutsch, B. (20II), "Social Tribes are more potent than Social Networks for Luxury Brands", Fashion' Collective (Online), $14^{\text {th }}$ June, http://fashionscollective.com/FashionAndLuxury/06/luxury-social-networks-versusluxury-tribes/ [Accessed: $2^{\text {nd }}$ Dec. 2012].

Foucault, M. (1989), The Archeology of Knowledge, London: Routledge.

Giddens, A. (199I), Modernity and Self-Identity: Self and Society in the Late Modern Age, Stanford, CA: Stanford University Press.

Gilmore, J.H. and Pine II, B.J. (2007), Authenticity - what consumers really want, Boston, MA: Harvard Business School Press.

Gilroy, P. (2002), There Ain't No Black in the Union Jack, London: Routledge Classics.

Grant, J. (2000), The New Marketing Manifesto: I 2 Rules for Building Successful Brands in the $21^{\text {st }}$ Century, London: Textere Publishing. 
Grant, J. (2003), After Image - Mind-altering Marketing, London: Profile Books Ltd.

Gilroy, P. (2004), After Empire, London: Routledge.

Grant, J. (2006), The Brand Innovation Manifesto - How to Build Brands, Redefine Markets and Defy Conventions, West Sussex: John Wiley \& Sons Ltd.

Grant, J. (2007), The Green Marketing Manifesto, West Sussex: John Wiley \& Sons Ltd.

Grant, J. (2010), Co-opportunity: Join Up for a Sustainable, Resilient, Prosperous World, West Sussex: John Wiley \& Sons Ltd.

Izberg-Bilgin, E. (forthcoming), "Infidel Brands: Unveiling Alternative Meanings of Global Brands at the Nexus of Globalization, Consumer Culture, and Islamism", Journal of Consumer Research.

Lévi-Strauss, C. (1968), Structural Anthropology, London: Allen Lane.

Liu, J. \& Wilson, J.A.J. (20II), "The impact of Culture and Religion on Leadership and Management Training: A Comparison of Three Continents”, Jurnal Pengurusan, 33, Pp.29-36.

Lyotard, J-F. ( 1984), The Postmodern Condition: A Report on Knowledge, Manchester: Manchester University Press.

McCracken, G. (1990a), Culture and Consumption: New Approaches to the Symbolic Character of Consumer Goods and Activities, Bloomington and Indianapolis: Indiana University Press.

McCracken, G. (1990b), Culture and Consumption II: Markets, Meaning and Brand Management, Bloomington and Indianapolis IN: Indiana University Press.

McCracken, G. (2008), Transformations: Identity Construction in Contemporary Culture, Bloomington and Indianapolis: Indiana University Press.

Negroponte, N. (1996), Being Digital, New York: Vintage Books.

Rigby, D. (20II), “The Future of Shopping”, Harvard Business Review, December, pp.64-77.

Roskin, M.G. and Coyle, J.J. (2008), Politics of the Middle East, $2^{\text {nd }}$ Edition, New Jersey: Pearson Education Inc.

Said, E. (1985), Orientalism, Harmondsworth: Penguin.

Said, E. (1993), Culture and Imperialism, New York: Vintage Books.

Saussure, F.d. (1974), Course in General Linguistics, London: Fontana.

Sirkin, H.L., Hemerling, J.W. and Bhattacharya, A.K. (2008), Globality - Competing with

Everyone, from Everywhere, for Everything, London: Headline Publishing Group.

Sontag, S. (1966), Against Interpretation, New York: Deli.

SPACE.com (20I2), “World's Highest Skydive Post-Jump Press Conference”, (Online Webcast), I $4^{\text {th }}$ October, http://www.space.com/I7956-red-bull-stratos-skydive-livevideo.html [Accessed: 2nd Dec. 20I2].

Storey, J. (2009), Cultural Theory and Popular Culture - An Introduction, $5^{\text {th }}$ Edition, Harlow: Pearson Education Ltd.

Thompson, R.F. (1983), Flash of the Spirit, New York: Random House. 
Wilson, J.A.J. (2010), "When in Britain, do as the British do - if anyone knows that that means. Multiculturalism in a 'British' university business school”, Multicultural Education and Technology Journal, Vol.4 Issue 4, pp.220-233.

Wilson, J.A.J. (2012a), The Brand, Culture \& Stakeholder-based Brand Management phenomenon: An International Delphi Study, PhD Thesis, Brunel University, UK.

Wilson, J.A.J. (20I2b), "Islamic Leadership: Bedouins in the Boardroom and profiting from Prophethood - Lessons from John Adair", TMC Academic Journal, Vol.6 Iss.2, pp.48-62.

Wilson, J.A.J. \& Liu, J. (20I I), "The Challenges of Islamic Branding: navigating Emotions and Halal”, Journal of Islamic Marketing, Vol.2 Iss. I, pp.28-42.

Wright, W. (1975), Sixguns and Society: A Structural Study of the Western, Berkeley: University of California Press. 